OPEN ACCESS

Edited by:

Chih-Ho Lai,

Chang Gung University, Taiwan

Reviewed by:

Michael Bukrinsky,

George Washington University,

United States

Vincenzo Mattei,

Sabina Universitas, Italy

${ }^{*}$ Correspondence:

Rakesh Kulkarni

rakeshkulkarni8@gate.sinica.edu.tw

Wen Chang

mbwen@ccvax.sinica.edu.tw

Specialty section:

This article was submitted to

Microbial Immunology,

a section of the journal

Frontiers in Immunology

Received: 14 November 2021

Accepted: 31 December 2021

Published: 20 January 2022

Citation:

Kulkarni R, Wiemer EAC and Chang W (2022) Role of Lipid Rafts in PathogenHost Interaction - A Mini Review.

Front. Immunol. 12:815020. doi: 10.3389/fimmu.2021.815020

\section{Role of Lipid Rafts in Pathogen-Host Interaction - A Mini Review}

\author{
Rakesh Kulkarni ${ }^{1,2 *}$, Erik A. C. Wiemer ${ }^{3}$ and Wen Chang ${ }^{2 *}$ \\ ${ }_{1}^{1}$ Molecular and Cell Biology, Taiwan International Graduate Program, National Defense Medical Center, Academia Sinica and \\ Graduate Institute of Life Science, Taipei, Taiwan, ${ }^{2}$ Institute of Molecular Biology, Academia Sinica, Taipei, Taiwan, ${ }^{3}$ Medical \\ Oncology, Erasmus MC Cancer Institute, University Medical Center Rotterdam, Netherlands
}

Lipid rafts, also known as microdomains, are important components of cell membranes and are enriched in cholesterol, glycophospholipids and receptors. They are involved in various essential cellular processes, including endocytosis, exocytosis and cellular signaling. Receptors are concentrated at lipid rafts, through which cellular signaling can be transmitted. Pathogens exploit these signaling mechanisms to enter cells, proliferate and egress. However, lipid rafts also play an important role in initiating antimicrobial responses by sensing pathogens via clustered pathogen-sensing receptors and triggering downstream signaling events such as programmed cell death or cytokine production for pathogen clearance. In this review, we discuss how both host and pathogens use lipid rafts and associated proteins in an arms race to survive. Special attention is given to the involvement of the major vault protein, the main constituent of a ribonucleoprotein complex, which is enriched in lipid rafts upon infection with vaccinia virus.

Keywords: lipid rafts, vaccinia virus, major vault protein, pathogen-host interactions, cell entry

\section{INTRODUCTION}

The fluid mosaic model of biological membranes was proposed by Singer and Nicolson in 1972, whereby membranes are composed of uniform lipid bilayers in which select proteins randomly float (1). Later studies have contradicted this hypothesis, revealing instead the presence of detergentresistant and detergent-soluble fractions in cell membranes (2). This latter heterogeneity in cell membranes was identified to be due to the presence of lipid rafts or microdomains (3-5). Lipid rafts are small, dynamic, heterogeneous microdomains $(10-200 \mathrm{~nm})$ that are enriched in cholesterol and glycophospholipids (6-9). High concentrations of sphingolipids and dense packing of protein with cholesterol in lipid rafts promotes cell membrane stability (10). Lipid rafts also contain a diverse group of cellular receptors (11-15) which play important roles in various cellular processes such as endocytosis, exocytosis, receptor trafficking and cell signaling (4). However, these same lipid rafts are also exploited by many pathogens to achieve cell entry and cell exit e.g. via budding $(8,16)$.

\footnotetext{
Abbreviations: ACE2, Angiotensin converting enzyme 2; CLEC5A, C-type lectin 5A; DC-SIGN, Dendritic CellSpecific Intercellular adhesion molecule-3-Grabbing Non-integrin; GKN3, Gastrokinase 3; PLVAP, Plasmalemma vesicle associated protein; PMA- Phorbol 12-myristate 13-acetate; IGF1R- Insulin like growth factor 1 receptor; Tim-1, T-cell immunoglobulin and mucin domain-1; CAR-Coxsakievirus and adenovirus receptor; SCARB2 - Scavenger receptor B2; PSGL1 - P-selectin glycoprotein ligand-1; SLAM - Signaling lymphocytic activation molecule; Anx2 - Heparan sulfate and annexin II.
} 
Advancements in cell imaging approaches have allowed lipid rafts to be visualized in cells, with cholera toxin staining frequently used for confocal microscopy-based observations (17). Lipid rafts are relatively resistant to extraction by non-ionic detergents such as $1 \%$ Triton $\mathrm{X}-100$ $(4,18,19)$, but biochemical enrichment by detergent extraction followed by flotation centrifugation has enabled more detailed analyses of lipid rafts. Many lipid raft-specific markers have been identified, including flotillin and caveolin $(12,15)$. Important tools to study the impact of lipid rafts in various cell signaling pathways are methyl- $\beta$ cyclodextrin $(\mathrm{M} \beta \mathrm{CD})$, filipin and nystatin. These compounds are used to extract cholesterol from the plasma membrane and through preferentially targeting cholesterol in lipid rafts, depletes the raft structures $(20,21)$. Lipid rafts are also found in multiple cells types in brain such as neurons, astrocytes and microglia; several neurodegerative diseases, such as Alzheimer's, Parkinson's, Huntington's, multiple sclerosis and lysosomal storage disease were found to be associated with altered composition of lipid rafts (22-26). Overall, lipid rafts modulate multiple aspects of cellular functions that are important for cell survival, immune signaling as well as pathogen recognition and pathogen egression (Figure 1A), as described below.

A

\section{Pathogen recognition}

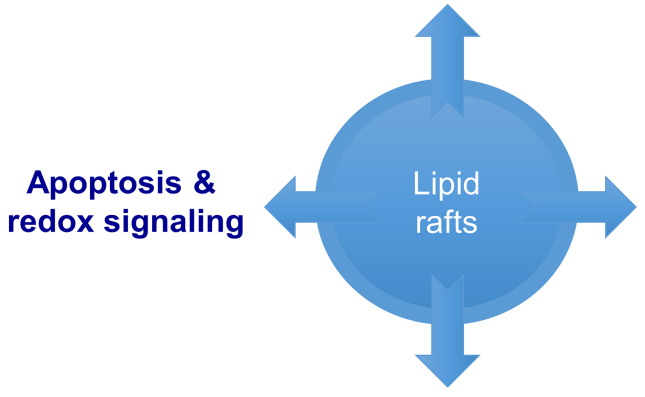

TLR signaling

\& cytokine secretion

Pathogen egress

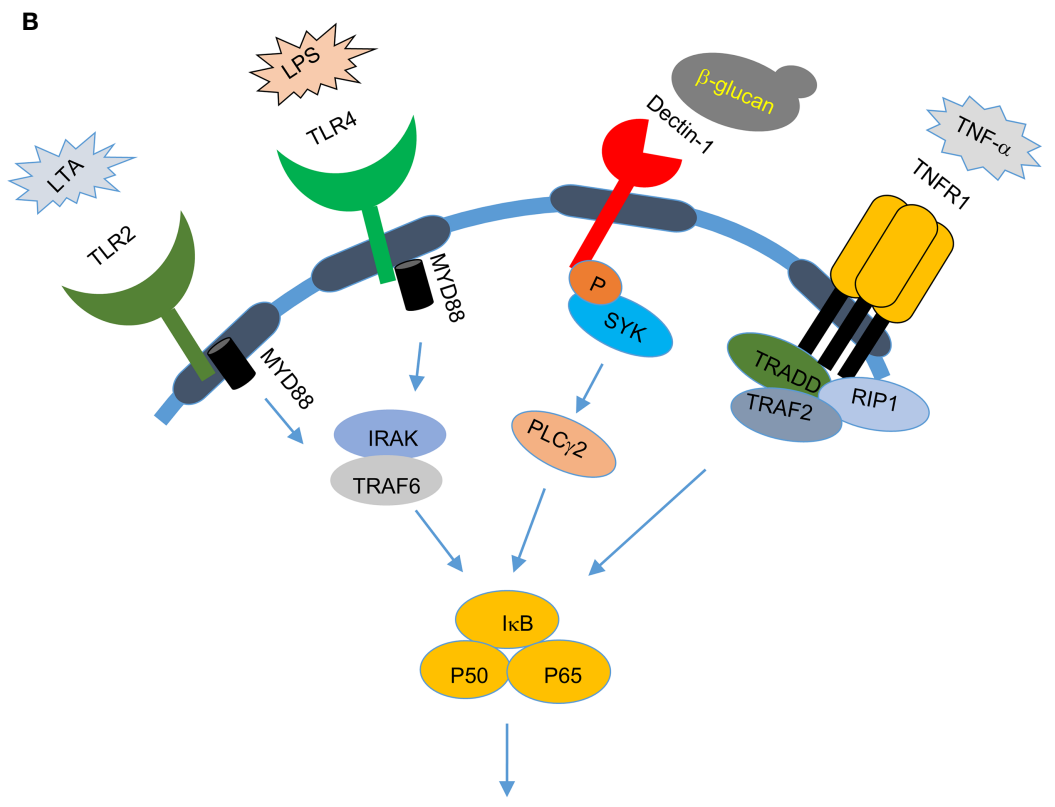

Pro-inflammatory cytokines

FIGURE 1 | Biological roles of lipid rafts in pathogen-host interactions: (A) Lipid rafts are involved in several cellular functions, such as pathogen recognition, cell signaling, and pathogen egress which decides the outcome of pathogen-host interaction. (B) Lipid rafts in pathogen sensing and cytokine release: Lipid rafts play an important role in pathogen sensing by recruiting pathogen sensing receptors such as toll like receptors when cells are stimulated with bacterial cell wall components LPS or LTA and C-type lectin receptors when stimulated with fungal cell wall components such as $\beta$-glucans which evetually leads to cytokine secretion. 


\section{LIPID RAFT INVOLVEMENT IN PATHOGEN RECOGNITION RECEPTOR SIGNALING AND CYTOKINE SECRETION}

Lipid rafts play important roles in modulating host innate and adaptive immune responses against pathogens. Apart from harboring proteins important for phagocytosis of pathogens (27-29), lipid rafts accumulate pathogen recognition receptors including c-type lectin receptors (CLRs) and Toll-like receptors (TLRs) - to detect pathogens and initiate downstream signaling cascades for cytokine release and complement system activation for pathogen clearance (30-32) (Figure 1B). TLR4 was found to be enriched in lipid raft fractions from cells stimulated with the specific ligand lipopolysaccharide (LPS), but not from nonstimulated cells, and depletion of lipid rafts by nystatin and filipin resulted in failure to produce the downstream cytokine TNF- $\alpha$; suggesting that lipid rafts are important in TLR4 activation (33). Another TLR, Toll-like receptor 2 (TLR2) that recognizes cell wall components of lipoteichoic acid (LTA) in Gram-positive bacteria, is enriched in lipid rafts and transported to Golgi network upon cell treatment with LTA (34-36). Depletion of lipid rafts by $\mathrm{M} \beta \mathrm{CD}$ or nystatin inhibited this enrichment of TLR2 and its transport to Golgi, implying a role for lipid rafts in TLR2 activation and trafficking (34-36). Similarly, host C-type lectins that sense carbohydrate-rich domains on fungi and activate downstream signaling events were also observed to be enriched in lipid rafts (37). Dectin-1 that is primarily expressed on dendritic cells, macrophages and neutrophils plays an important role in anti-fungal immunity (38). Upon sensing fungal zymosan or $\beta$-glucan, host dectin-1 was found to translocate with its downstream signaling molecules spleen tyrosine kinase (SYK) and phospholipase C gamma 2 (PLC $\gamma$ ) to lipid rafts. Depletion of lipid rafts by MBCD treatment resulted in loss of SYK phosphorylation in dendritic cells, supporting a role for lipid rafts in dectin-1 signaling (39). During Streptococcus pneumoniae infection, splenic marginal zone (MZ) macrophage lipid rafts accelerate pathogen uptake and degradation (40), as well as mediate DC-SIGN- or SIGN-R1-induced classical complement pathway activation against $S$. pneumoniae, thereby facilitating rapid clearance of this pathogen.

Cytokines are soluble factors released by cells in response to infection and inflammation and they are key modulators of the immune system. Cytokine receptors are recruited to lipid rafts to mediate cytokine signaling. For example, tumor necrosis factor- $\alpha$ receptor 1 (TNFR1) and interferon alpha and beta receptor subunit 1 (IFNAR1) are enriched in lipid rafts, and depletion of lipid rafts reduced cytokine release $(41,42)$. Furthermore, release of cytokines from vesicles requires N-ethylmaleimide sensitive factor attachment protein receptor (SNARE) mediated fusion with the plasma membrane. SNARE proteins, including syntaxin 4 and synaptosomal associated protein-23, are enriched in lipid rafts of LPS-stimulated macrophages, facilitating release of the cytokine TNF- $\alpha$ (43). Other reports also showed that SNARE and Rab proteins are associated with lipid rafts $(44,45)$.

It is interesting that, although cytokine release is dependent on lipid rafts, the integrity of lipid rafts is also reciprocally affected by cytokine signaling. For example, interferon-induced viperin interacts with farnesyl diphosphate synthase (FPPS) to inhibit cholesterol synthesis and lipid raft formation (46), in addition to its role in catalyzing cytidine triphosphate (CTP) to $3^{\prime}$-deoxy-3',4'-didehydro-CTP (ddhCTP) $(46,47)$.

\section{ROLE OF LIPID RAFTS IN APOPTOSIS AND REDOX SIGNALING}

Reactive oxygen species (ROS) produced in phagosomes eliminate pathogens through oxidative damage by innate immune cells such as neutrophils (48), representing an important element of inflammation and antimicrobial host defense. Nicotinamide adenine dinucleotide phosphate oxidase (NOX) is a key source of ROS in host cells. NOX is a multimer that requires all components for assembly and enzymatic activity in lipid rafts to produce ROS (49). Depletion of lipid rafts limits ROS production due to failure to recruit cytosolic components of the NOX complex (i.e., $\mathrm{P} 47^{\text {phox }}, \mathrm{P} 67^{\text {phox }}, \mathrm{P} 40^{\text {phox }}$ and RAC) to the plasma membrane, which already harbors the $\mathrm{gp} 91^{\text {phox }}$ and $\mathrm{P} 22^{\text {phox }}$ components upon priming with interleukin 8 (Il-8) (5052).Other adaptor molecules, such as protein kinase $C$ involved in phosphorylating the NOX subunit $\mathrm{P} 47^{\text {phox }}$, are also recruited to lipid rafts for ROS production. In another study, Mycobacterium tuberculosis 19-KDa lipoprotein, which is a TLR1/2 agonist, was shown to trigger translocation of TLR2 and protein kinase $\mathrm{C} \zeta$ to lipid rafts and to induce ROS production (52). Disruption of lipid rafts in macrophages resulted in reduced $M$. tuberculosis lipoprotein-induced ROS production and recruitment of TLR2 and protein kinase $C \zeta$, demonstrating that lipid rafts are critical to ROS production. Low doses of ROS under steady-state conditions contribute to cell survival, whereas high doses of ROS induced by infection help clear pathogens by activating cell death pathways such as apoptosis and necroptosis. In the TNF (tumor necrosis factor)induced necroptosis pathway, activation of mixed lineage kinase domain-like protein (MLKL) lead to oligomerization of receptorinteracting protein3 (RIPK3) which is translocated to lipid rafts in the plasma membrane where it enhances sodium influx to induce cell rupture (53). Lipid rafts also regulate other cell death pathways such as autophagy. Lipid rafts are found in mitochondria associated membranes that connect ER with mitochondria and are required for the correct assembly of vesicles and formation of autophagosomes (54-56).

\section{CELLULAR ENTRY OR EGRESS OF PATHOGENS VIA LIPID RAFTS}

Host-pathogen interactions determine the outcome of infections. Lipid rafts are a key component of host-pathogen interactions on cell surfaces, given their roles in initiating cell signaling, harboring receptors and mediating cell trafficking (57-59). Experimental drugs that interrupt lipid raft formation have 
demonstrated that lipid rafts are important for cell entry of multiple viruses (Table 1). HIV-1 viral protein gp120 fuses with $\mathrm{CD}^{+}$T-cells through the lipid raft-associated receptors CD4, CCR5 and CXCR4 (60-62). Vaccinia mature virus (MV) clusters on lipid rafts where it interacts with the type II glycoprotein CD98 and integrin $\beta 1$ to trigger endocytosis for cell entry $(66,67$, 124). Both depletion of lipid rafts and knockdown of CD98 have been shown to reduce $\mathrm{MV}$ endocytosis, supporting the importance of lipid rafts in vaccinia virus entry into cells (66, 67). Hemagglutinin (HA) glycoprotein of influenza virus is important for virus-cell attachment and membrane fusion, which occurs more efficiently at lipid rafts of plasma membrane, suggesting that influenza virus employs lipid rafts for cell entry (69-71). Simian virus 40 (SV40), upon infection in cells, translocated to caveolae enriched membranes and specific disruption of caveolae with phorbol ester PMA or nystatin blocked SV40 entry (71). Human herpes virus-6 (HHV-6) enters cells through binding to cellular receptor CD46, which was enriched in lipid (74-77). As expected, depletion of cholesterol inhibited HHV-6 entry into cells (74-77). Similarly, poliovirus and type $c$ foot-and mouth disease virus (FMDV) entry into the cells was also inhibited upon treatment with M $\beta C D$ and was reversed upon addition of cholesterol suggesting role of lipid rafts in their entry $(78,79,87)$. Flavivirus family members Japanese encephalitis virus (JEV), dengue virus serotype-2 (DEN-2) and West Nile virus (WNV) infection to cells was inhibited upon treatment with M $\beta C D$ and cholesterol chelator filipin III. Surprisingly addition of cholesterol did not rescue cell susceptibility to JEV and DEN-2, unlike other viruses $(81,87)$. Several coronavirus family members such as mouse hepatitis virus (MHV), infectious bronchitis virus (IBV), human coronavirus 229E (HcoV-229E), severe acute respiratory syndrome virus (SARS-CoV), were shown to enter cells through lipid rafts $(89,91,93,96)$. A recent report also showed that pseudotyped virus containing SARS-CoV-2 spike protein enters cells through lipid rafts (99). African swine fever virus (ASFV) entry into pig macrophages is also dependent on lipid rafts as depletion of lipid rafts with cyclodextrins and nystatin blocked ASFV entry into pig macrophages $(103,104)$. Apart from viruses, bacterial pathogens also target lipid rafts during infection. For example, the enteric Gram-negative bacteria Shigella flexneri and Salmonella enterica enter cells by binding to lipid raftassociated receptors CD44 and CD55, respectively (125, 126). Depletion of lipid rafts impedes bacteria from binding to and entering host cells (127).

However, there are also studies indicating an opposing role for a lipid raft-associated protein, caveolin, during endocytic entry of the bacteria Staphylococcus aureus (128). Engagement of $S$. aureus by host integrin $\alpha 5 \beta 1$ via fibronectin was shown to trigger bacterial relocalization to lipid rafts. Surprisingly, caveolin deficiency, but not flotillin deficiency, enhanced $S$. aureus uptake. Recruitment of membrane lipids to the bacterial attachment site was not affected in $\mathrm{Cav1}^{-/-}$cells, suggesting that caveolin blocks S. aureus in a post-attachment step (128). Caveolin has also been proven essential in host defenses against the pathogens Pseudomonas aeruginosa and Salmonella enterica sv. Typhimurium $(129,130)$. Caveolin-knockout mice are susceptible to both bacteria, exhibiting increased bacterial burdens in several organs relative to non-infected controls (129, 130). It is interesting that caveolin-knockout mice display a severe inflammatory phenotype, with elevated levels of

TABLE 1 | Lipid raft mediated viral entry and receptors involved.

\begin{tabular}{|c|c|c|c|}
\hline Virus & Receptors & Chemical and pharmaceutical drugs targeting lipid rafts & References \\
\hline Human immunodeficiency virus & CD4, CCR5, CXCR4 & MßCD, Cytochalasin, Nystatin, 25-Hydroxycholesterol, Atorvastatin & $(60-65)$ \\
\hline Vaccinia virus & CD98, Integrin $\beta 1$ & $\mathrm{M} \beta C D$ & $(66-68)$ \\
\hline Influenza & Sialic acid & M $\beta C D$, Cyclodextrin, Fluvastatin & $(69-72)$ \\
\hline Simian virus 40 & Ganglioside GM1 & PMA, Nystatin, Filipin III & $(71,73)$ \\
\hline Human herpes virus-6 & CD46 & $\mathrm{M} \beta C D$ & $(74-77)$ \\
\hline Polio virus & CD155 & $M \beta C D$ & (78) \\
\hline Foot-and-mouth disease virus & Integrin $\alpha v \beta 6$ & $\mathrm{M} \beta \mathrm{CD}$ & $(79,80)$ \\
\hline Japanese encephalitis virus & PLVAP, GKN3 & MßCD, Filipin III & $(81,82)$ \\
\hline Dengue virus & DC-SIGN, Mannose receptor, CLEC5A & MßCD, Filipin III, Cyclodextrins, Propofol,2,6-diisopropylphenol & $(81,83-86)$ \\
\hline West Nile virus & TLR3 & $\mathrm{M} \beta C D$ & $(87,88)$ \\
\hline Mouse hepatitis virus & CD66a & MßCD, Filipin III & $(89,90)$ \\
\hline Infectious bronchitis virus & Sialic acid & M $\beta C D$, Mevastatin & $(91,92)$ \\
\hline Human coronavirus 229E & CD13 & $\mathrm{M} \beta \mathrm{CD}$, Chloroquine & $(93-95)$ \\
\hline SARS-CoV & ACE2 & M $\beta C D$, Cholesterol 25-Hydroxylase & $(96-98)$ \\
\hline SARS-CoV-2 & ACE2 & MßCD, Fluvoxamine, 25-Hydroxycholesterol, Fluvastatin & $(98-102)$ \\
\hline African swine fever virus & CD163 & Cyclodextrins, Nystatin & $(103,104)$ \\
\hline Zika virus & DC-SIGN, AXL, Tyro3, Tim-1 & 25-Hydroxycholesterol, Chloroquine & $(83,105,106)$ \\
\hline Hepatitis C virus & CD81, DC-SIGN, CD209L & Fluvastatin & $(107,108)$ \\
\hline Respiratory Syncytial virus & CX3CR1, IGF1R & Lovastatin, Cyclodextrins & $(83,109-112)$ \\
\hline Ebola virus & Tim-1 & Lovastatin, cyclodextrins & $(113,114)$ \\
\hline Herpes simplex virus & Heparan sulfate & Cyclodextrins & $(83,115)$ \\
\hline Coxsackievirus & CAR & Fluoxetine & $(116)$ \\
\hline Enterovirus 71 & SCARB2, Anx2, PSGL-1, sialylated glycan & Fluoxetine & $(116-119)$ \\
\hline Measles virus & CD46, SLAM & Halothane & $(120,121)$ \\
\hline Murine Cytomegalovirus & Heparan sulfate & Simvastatin & $(122,123)$ \\
\hline
\end{tabular}


inflammatory cytokines, chemokines in serum, and free radicals, implying complex biological functions of lipid raft-associated proteins in pathogen and host interactions (131). Pathogen interactions with lipid rafts are not solely restricted to the cell surface, since many intracellular pathogens could escape degradation by preventing phagosome fusion with lysosomes upon being internalized into cells (132). For example, Leishmania donovani utilizes lipophosphoglycans to disrupt dynein in lipid rafts and thereby avoids lysosomal degradation (132).

As for pathogen entry into cells, pathogen assembly and egress is crucial for its spread to other cells, tissues and hosts. Pathogens can manipulate the egress route by inducing programmed cell death (e.g., apoptosis) and cell rupture, by forming actin-mediated protrusions, or by inducing bud formation, with this latter potentially involving lipid rafts. Endosomal sorting complexes required for transport (ESCRT) are essential for membrane scission, as well as being involved in viral budding. Many enveloped viruses such as HIV, Murine Leukemia Virus (MLV) and vaccinia virus employ ESCRT-dependent budding or egress mechanisms (133-136). Knockdown of ESCRT complex members such as charged multivesicular body protein -2A (CHMP-2A) and CHMP-4B blocked the release of HIV and MLV $(133,136)$. Proteomic analyses have revealed the presence of ESCRT complex proteins in isolated lipid raft fractions, implying a role in viral budding $(137,138)$. Cholesterol synthesis inhibitor lovastatin treatment reduced the dengue virus (DENV) production by blocking virion assembly and intracellular trafficking showing that lipid rafts are important not only for DENV entry but also for their release from cells (139).

\section{PHARMACEUTICAL DRUGS TARGETING LIPID RAFTS TO BLOCK PATHOGEN ENTRY AND INFECTION}

As described above, many pathogen attachment receptors are concentrated in the lipid rafts, hence targeting lipid rafts could be a good strategy to overcome infection $(140,141)$. Disruption of lipid rafts by chemical compounds such as $M \beta C D$, filipin, 25hydroxycholesterol and cyclodextrins has already shown to block the entry of many pathogens into cells $(63,81,83,100,105,142$, 143). Furthermore, several pharmaceutical drugs used in treatment of other disorders were found to interact with lipid rafts resulting in blocking the entry of pathogens into the cells. Some of the well-known drugs targeting lipid rafts are statins (144, 145), anesthetics (146), and psychotropic drugs (147-150). Several statins such as lovastatin, mevastatin, fluvastatin, simvastatin, atorvastatin and nystatin used for the treatment of cardiovascular disease were reported to block virus entry into cells $(64,65,72,101,107,109,110,113,122)$. Similarly, anesthetic drugs such as propofol, halothane and barbiturates were found to block virus entry due to their interaction with lipid rafts $(84,120)$. Antidepressants act by displacing $G$ protein responsible for increasing cAMP $\left(\mathrm{G} \alpha_{\mathrm{s}}\right)$ from lipid rafts, and drugs such as fluvoxamine, and fluoxetine are known to block the entry of viruses $(102,116-118,147,149)$. Taken together, repurposing these existing drugs against newly emerging pathogenic virus may provide a good strategy since they have a proven safety record and can be deployed in a short time to treat viral infections. The list of potential pharmaceutical drugs targeting lipid rafts to block entry and propagation of viruses are included in Table $\mathbf{1}$.

\section{MAJOR VAULT PROTEIN (MVP) MODULATES IMMUNE SIGNALING AND PATHOGEN ENTRY}

MVP is a $100-\mathrm{kDa}$ protein that constitutes the major component of vault complex in cells $(151,152)$. The vault particle is a huge (400 $\AA$ x $670 \AA$ ) cage-like structure of $12.9 \mathrm{Mda}$, consisting of MVP, vault poly (ADP-ribose) polymerase (VPARP/PARP4) and telomerase associated protein (TEP1) proteins and multiple copies of small untranslated vault RNAs (vRNAs) (153). MVP is widely expressed in many normal tissues and overexpressed in many multi-drug-resistant cancer cells (153155). MVP and vault particles may act as scaffolds for proteins involved in signal transduction, such as the Janus kinase/signal transducer and activator of transcription proteins (JAK/STAT) (156), Phosphoinositide-3-kinase/protein kinase B (PI3K/AKT) (125) and ERK (157) signaling pathways. MVP has also been implicated in suppression of metabolic diseases, such as obesity and atherosclerosis, through IKK-NF- $\mathrm{KB}$ signaling-mediated inflammation (158). MVP negatively regulates osteoclast differentiation by inhibiting the calcineurin-NFATc1 signaling pathway (159). Moreover, it interacts with Src in an epidermal growth factor (EGFR)-dependent manner and downregulates Src tyrosine kinase activity in stomach tissue, with this latter being necessary for activation of extracellular signal-regulated kinase (ERK) signaling (160).

Interestingly, MVP and vault particles also play a role in pathogen, host interactions. For instance, vRNA induced by Epstein-Barr viral infections played a role in anti-viral host defense $(161,162)$. MVP was found to be enriched in lipid rafts following infection of human lung epithelial cells with Pseudomonas aeruginosa (163). Binding of P. aeruginosa LPS outer-core oligosaccharide to cystic fibrosis transmembrane conductance (CFTR) recruited MVP to lipid rafts and activate $\mathrm{NF}-\mathrm{\kappa B}$ signaling, IL-8 secretion and apoptosis induction. In MVP knockout $\left(\mathrm{MVP}^{-/-}\right)$mice bacteria uptake in lungs was reduced to $45 \%$ when compared with the wild-type mice. Further analyses concluded that MVP is critical for formation of stable membrane microdomains after $P$. aeruginosa infection. MVP translocation to lipid rafts was also induced by microbial metabolites such as N-(3-oxo-dodecanoyl) homoserine lactones (C12) released by proteobacteria and Pseudomonas aeruginosa (164) to modulate p38 pathway to reduce apoptotic cell death (164). In macrophages, MVP interacted with the scavenger receptor (SR-A/MSR1) in membrane rafts and modulated SRA-caveolin-p38/JNK-mediated TNF- $\alpha$ production and apoptosis (165). MVP knockout (KO) mice grow normally showing that it 
is not required during mouse embryogenesis (166) and yet these KO mice are more susceptible to infection with several pathogens, such as Influenza A virus and Pseudomonas aeruginosa, suggesting that MVP plays an important role in immune responses against viral and bacterial pathogens (163, 167). In our previous study to identify cellular proteins enriched in lipid rafts upon vaccinia virus infection we identified integrin $\beta 1$ and CD98 proteins that play important roles in virus entry $(66,67)$. Interestingly, these proteomic data (66) (Figure 2A) also revealed MVP to be enriched $\sim 5$-fold in lipid rafts upon vaccinia virus infection (Figure 2B) (66). Increase of MVP in lipid rafts is transient and MVP is not involved in integrin $\beta 1$ or CD98 interactions and whether it participates in other signaling events during vaccinia mature virus entry remains to be investigated. The role of MVP in several immune signaling pathways, as summarized in (Figure 2C), showed that it may exert important functions in host-pathogen interactions, warranting further detailed experimental study.

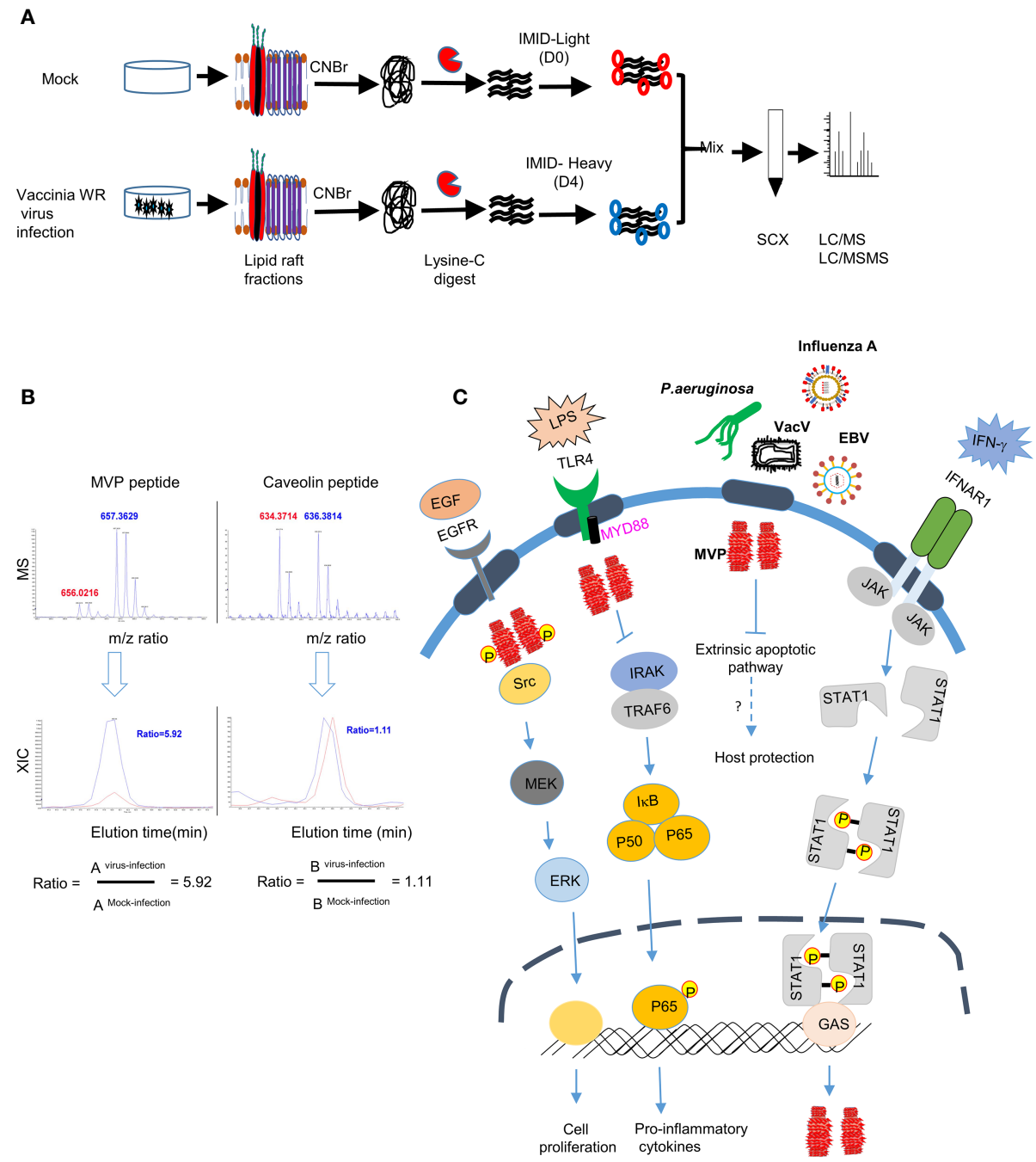

FIGURE 2 | MVP accumulates in lipid rafts after infection with vaccinia virus (A) Schematic representation of differential IMID-H4/D4 labeling and LC/MS/MS analyses of lipid raft-associated proteins isolated from HeLa cells that were either mock infected or infected with WR strain MV as previously described (66, 67). (CNBr, Cyanogen bromide, SCX, Strong cation exchange column, m/z, mass-to-charge ratio), (B) Differential protein association in lipid raft proteome derived from mock or vaccinia virus infected HeLa cells (66). Labelled peptides were quantitatively determined by lysine-specific isotope labeling scheme. Co-eluted peaks contained peptides from both virus infected cells (blue) and from mock-infected cells (red). The blue-to-red ratio determined whether abundance of one particular peptide after virus infection is increased $(>1)$, unchanged $(=1)$ or decreased $(<1)$. (C) Role of MVP in signaling pathways: MVP protein, the major component of vault particle, is recruited to the lipid rafts upon stimulation with growth factors (e.g., EGF) or pathogen derived ligands (e.g., LPS) and regulates important biological processes such as cell proliferation and cytokine secretion. IFNAR receptor stimulation with IFN- $\gamma$ in the lipid rafts activates JAK-STAT signaling pathway which in turn will lead to the transcription of MVP. MVP also plays an important role in regulating apoptotic signaling pathway on infection with pathogens such as $P$. aeruginosa and helps in host protection, however the detailed mechanism on how recruitment of MVP to the lipid rafts after infection with other pathogens such as VacV, EBV and influenza virus needs investigation. 


\section{CONCLUSION AND FUTURE PERSPECTIVES}

Lipid rafts on the plasma membrane are used as a portal for entry by many pathogens, including viruses and bacteria. Reorganization of cell surface lipid rafts during pathogen and virus entry could induce clustering of membrane receptors and/ or intracellular molecules at the proximal inner membrane to facilitate entry, as well as to trigger signaling cascades. Thus, formation of such raft-associated protein complexes may reflect how pathogens and viruses engage with particular cellular receptors required for cell entry and invasion, how cells sense stress and mount immediate early anti-viral and anti-bacterial responses, and may even explain how viral proteins hijack lipid rafts to modify or antagonize cellular signaling and allow their propagation. Our understanding of the dynamic processes and kinetics governing lipid raft formation is still limited. This is in part due to technical challenges as well as the variety of different proteins found to be recruited to lipid rafts. Furthermore, one needs reliable and sensitive methods to modulate and monitor composition, molecular interactions and functionality in time, preferably in intact cells/tissues being challenged with pathogens.

\section{REFERENCES}

1. Singer SJ, Nicolson GL. The Fluid Mosaic Model of the Structure of Cell Membranes. Science (1972) 175(4023):720-31. doi: 10.1126/science. 175.4023.720

2. Steck TL, Yu J. Selective Solubilization of Proteins From Red Blood Cell Membranes by Protein Perturbants. J Supramol Struct (1973) 1(3):220-32. doi: $10.1002 /$ jss. 400010307

3. Karnovsky MJ, Kleinfeld AM, Hoover RL, Klausner RD. The Concept of Lipid Domains in Membranes. J Cell Biol (1982) 94(1):1-6. doi: 10.1083/jcb.94.1.1

4. Simons K, Ikonen E. Functional Rafts in Cell Membranes. Nature (1997) 387 (6633):569-72. doi: 10.1038/42408

5. Lingwood D, Kaiser HJ, Levental I, Simons K. Lipid Rafts as Functional Heterogeneity in Cell Membranes. Biochem Soc Trans (2009) 37(Pt 5):95560. doi: 10.1042/BST0370955

6. Pike LJ. Rafts Defined: A Report on the Keystone Symposium on Lipid Rafts and Cell Function. J Lipid Res (2006) 47(7):1597-8. doi: 10.1194/ jlr.E600002-JLR200

7. Levental I, Veatch S. The Continuing Mystery of Lipid Rafts. J Mol Biol (2016) 428(24 Pt A):4749-64. doi: 10.1016/j.jmb.2016.08.022

8. Sezgin E, Levental I, Mayor S, Eggeling C. The Mystery of Membrane Organization: Composition, Regulation and Roles of Lipid Rafts. Nat Rev Mol Cell Biol (2017) 18(6):361-74. doi: 10.1038/nrm.2017.16

9. Levental I, Levental KR, Heberle FA. Lipid Rafts: Controversies Resolved, Mysteries Remain. Trends Cell Biol (2020) 30(5):341-53. doi: 10.1016/ j.tcb.2020.01.009

10. Sezgin E, Kaiser HJ, Baumgart T, Schwille P, Simons K, Levental I. Elucidating Membrane Structure and Protein Behavior Using Giant Plasma Membrane Vesicles. Nat Protoc (2012) 7(6):1042-51. doi: 10.1038/nprot.2012.059

11. Otto GP, Nichols BJ. The Roles of Flotillin Microdomains-Endocytosis and Beyond. J Cell Sci (2011) 124(Pt 23):3933-40. doi: 10.1242/jcs.092015

12. Bickel PE, Scherer PE, Schnitzer JE, Oh P, Lisanti MP, Lodish HF. Flotillin and Epidermal Surface Antigen Define a New Family of Caveolae-Associated Integral Membrane Proteins. J Biol Chem (1997) 272(21):13793-802. doi: $10.1074 /$ jbc.272.21.13793

13. Stuermer CA, Lang DM, Kirsch F, Wiechers M, Deininger SO, Plattner H. Glycosylphosphatidyl Inositol-Anchored Proteins and Fyn Kinase Assemble in Noncaveolar Plasma Membrane Microdomains Defined by Reggie-1 and -2. Mol Biol Cell (2001) 12(10):3031-45. doi: 10.1091/mbc.12.10.3031
Reports in the literature highlight important, if not key roles for MVP recruited to lipid rafts upon pathogen exposure. Therefore, further detailed investigations are warranted to reveal the full functional potential of MVP in dealing with diverse pathogens in different cell types. A better and more precise delineation of the cellular function(s) of MVP, as well as the other components of the vault complex, will reveal interesting biology and possibly therapeutic opportunities.

\section{AUTHOR CONTRIBUTIONS}

RK, WC, and EW wrote and revised the manuscript. All authors contributed to the article and approved the submitted version.

\section{FUNDING}

WC was supported by a grant from the Academia Sinica and Ministry of Science and Technology (110-2320-B-001015-MY3).

14. Mora R, Bonilha VL, Marmorstein A, Scherer PE, Brown D, Lisanti MP, et al. Caveolin-2 Localizes to the Golgi Complex But Redistributes to Plasma Membrane, Caveolae, and Rafts When Co-Expressed With Caveolin-1. J Biol Chem (1999) 274(36):25708-17. doi: 10.1074/jbc.274.36.25708

15. Wilson BS, Steinberg SL, Liederman K, Pfeiffer JR, Surviladze Z, Zhang J, et al. Markers for Detergent-Resistant Lipid Rafts Occupy Distinct and Dynamic Domains in Native Membranes. Mol Biol Cell (2004) 15(6):2580 92. doi: 10.1091/mbc.e03-08-0574

16. Head BP, Patel HH, Insel PA. Interaction of Membrane/Lipid Rafts With the Cytoskeleton: Impact on Signaling and Function: Membrane/Lipid Rafts, Mediators of Cytoskeletal Arrangement and Cell Signaling. Biochim Biophys Acta (2014) 1838(2):532-45. doi: 10.1016/j.bbamem.2013.07.018

17. Kenworthy AK, Petranova N, Edidin M. High-Resolution FRET Microscopy of Cholera Toxin B-Subunit and GPI-Anchored Proteins in Cell Plasma Membranes. Mol Biol Cell (2000) 11(5):1645-55. doi: 10.1091/mbc.11.5.1645

18. Brown DA, Rose JK. Sorting of Gpi-Anchored Proteins to GlycolipidEnriched Membrane Subdomains During Transport to the Apical CellSurface. Cell (1992) 68(3):533-44. doi: 10.1016/0092-8674(92)90189-J

19. Aureli M, Grassi S, Sonnino S, Prinetti A. Isolation and Analysis of Detergent-Resistant Membrane Fractions. Methods Mol Biol (1376) 2016:107-131. doi: 10.1007/978-1-4939-3170-5_10

20. Christian AE, Haynes MP, Phillips MC, Rothblat GH. Use of Cyclodextrins for Manipulating Cellular Cholesterol Content. J Lipid Res (1997) 38 (11):2264-72. doi: 10.1016/S0022-2275(20)34940-3

21. Castanho MA, Coutinho A, Prieto MJ. Absorption and Fluorescence Spectra of Polyene Antibiotics in the Presence of Cholesterol. J Biol Chem (1992) 267 (1):204-9. doi: 10.1016/S0021-9258(18)48480-3

22. Valsecchi M, Mauri L, Casellato R, Prioni S, Loberto N, Prinetti A, et al. Ceramide and Sphingomyelin Species of Fibroblasts and Neurons in Culture. J Lipid Res (2007) 48(2):417-24. doi: 10.1194/jlr.M600344-JLR200

23. Sonnino S, Aureli M, Grassi S, Mauri L, Prioni S, Prinetti A. Lipid Rafts in Neurodegeneration and Neuroprotection. Mol Neurobiol (2014) 50(1):130 48. doi: 10.1007/s12035-013-8614-4

24. Chiricozzi E, Biase ED, Maggioni M, Lunghi G, Fazzari M, Pome DY, et al. GM1 Promotes TrkA-Mediated Neuroblastoma Cell Differentiation by Occupying a Plasma Membrane Domain Different From TrkA. J Neurochem (2019) 149(2):231-41. doi: 10.1111/jnc.14685

25. Chiricozzi E, Lunghi G, Di Biase E, Fazzari M, Sonnino S, Mauri L. GM1 Ganglioside Is A Key Factor in Maintaining the Mammalian Neurona 
Functions Avoiding Neurodegeneration. Int J Mol Sci (2020) 21(3):868. doi: 10.3390/ijms21030868

26. Grassi S, Giussani P, Mauri L, Prioni S, Sonnino S, Prinetti A. Lipid Rafts and Neurodegeneration: Structural and Functional Roles in Physiologic Aging and Neurodegenerative Diseases. J Lipid Res (2020) 61(5):636-54. doi: 10.1194/jlr.TR119000427

27. Nakayama H, Yoshizaki F, Prinetti A, Sonnino S, Mauri L, Takamori K, et al. Lyn-Coupled LacCer-Enriched Lipid Rafts Are Required for CD11b/CD18Mediated Neutrophil Phagocytosis of Nonopsonized Microorganisms. J Leukoc Biol (2008) 83(3):728-41. doi: 10.1189/jlb.0707478

28. Nakayama H, Kurihara H, Morita YS, Kinoshita T, Mauri L, Prinetti A, et al. Lipoarabinomannan Binding to Lactosylceramide in Lipid Rafts Is Essential for the Phagocytosis of Mycobacteria by Human Neutrophils. Sci Signal (2016) 9(449):ra101. doi: 10.1126/scisignal.aaf1585

29. Chiricozzi E, Ciampa MG, Brasile G, Compostella F, Prinetti A, Nakayama $\mathrm{H}$, et al. Direct Interaction, Instrumental for Signaling Processes, Between LacCer and Lyn in the Lipid Rafts of Neutrophil-Like Cells. J Lipid Res (2015) 56(1):129-41. doi: 10.1194/jlr.M055319

30. Barnett KC, Kagan JC. Lipids That Directly Regulate Innate Immune Signal Transduction. Innate Immun (2020) 26(1):4-14. doi: 10.1177/ 1753425919852695

31. Koberlin MS, Heinz LX, Superti-Furga G. Functional Crosstalk Between Membrane Lipids and TLR Biology. Curr Opin Cell Biol (2016) 39:28-36. doi: 10.1016/j.ceb.2016.01.010

32. Varshney P, Yadav V, Saini N. Lipid Rafts in Immune Signalling: Current Progress and Future Perspective. Immunology (2016) 149(1):13-24. doi: $10.1111 / \mathrm{imm} .12617$

33. Triantafilou M, Miyake K, Golenbock DT, Triantafilou K. Mediators of Innate Immune Recognition of Bacteria Concentrate in Lipid Rafts and Facilitate Lipopolysaccharide-Induced Cell Activation. J Cell Sci (2002) 115 (Pt 12):2603-11. doi: 10.1242/jcs.115.12.2603

34. Triantafilou M, Manukyan M, Mackie A, Morath S, Hartung T, Heine H, et al. Lipoteichoic Acid and Toll-Like Receptor 2 Internalization and Targeting to the Golgi Are Lipid Raft-Dependent. J Biol Chem (2004) 279 (39):40882-9. doi: 10.1074/jbc.M400466200

35. Soong G, Reddy B, Sokol S, Adamo R, Prince A. TLR2 Is Mobilized Into an Apical Lipid Raft Receptor Complex to Signal Infection in Airway Epithelial Cells. J Clin Invest (2004) 113(10):1482-9. doi: 10.1172/JCI20773

36. John V, Kotze LA, Ribechini E, Walzl G, Du Plessis N, Lutz MB. Caveolin-1 Controls Vesicular TLR2 Expression, P38 Signaling and T Cell Suppression in BCG Infected Murine Monocytic Myeloid-Derived Suppressor Cells. Front Immunol (2019) 10:2826. doi: 10.3389/fimmu.2019.02826

37. Cambi A, Koopman M, Figdor CG. How C-Type Lectins Detect Pathogens. Cell Microbiol (2005) 7(4):481-8. doi: 10.1111/j.1462-5822.2005.00506.x

38. Rella A, Farnoud AM, Del Poeta M. Plasma Membrane Lipids and Their Role in Fungal Virulence. Prog Lipid Res (2016) 61:63-72. doi: 10.1016/ j.plipres.2015.11.003

39. Xu S, Huo J, Gunawan M, Su IH, Lam KP. Activated Dectin-1 Localizes to Lipid Raft Microdomains for Signaling and Activation of Phagocytosis and Cytokine Production in Dendritic Cells. J Biol Chem (2009) 284(33):2200511. doi: $10.1074 /$ jbc.M109.009076

40. Yang SW, Park JY, Choi H, Yun TJ, Choi WS, Kim MK, et al. Dominant Role of Splenic Marginal Zone Lipid Rafts in the Classical Complement Pathway Against S. Pneumoniae. Cell Death Discov (2019) 5:133. doi: 10.1038/ s41420-019-0213-3

41. Legler DF, Micheau O, Doucey MA, Tschopp J, Bron C. Recruitment of TNF Receptor 1 to Lipid Rafts Is Essential for TNFalpha-Mediated NF-kappaB Activation. Immunity (2003) 18(5):655-64. doi: 10.1016/s1074-7613(03)00092-x

42. Santos AL, Preta G. Lipids in the Cell: Organisation Regulates Function. Cell Mol Life Sci (2018) 75(11):1909-27. doi: 10.1007/s00018-018-2765-4

43. Kay JG, Murray RZ, Pagan JK, Stow JL. Cytokine Secretion via CholesterolRich Lipid Raft-Associated SNAREs at the Phagocytic Cup. J Biol Chem (2006) 281(17):11949-54. doi: 10.1074/jbc.M600857200

44. Chamberlain LH, Burgoyne RD, Gould GW. SNARE Proteins Are Highly Enriched in Lipid Rafts in PC12 Cells: Implications for the Spatial Control of Exocytosis. Proc Natl Acad Sci USA (2001) 98(10):5619-24. doi: 10.1073/ pnas. 091502398
45. Zerial M, McBride H. Rab Proteins as Membrane Organizers. Nat Rev Mol Cell Biol (2001) 2(2):107-17. doi: 10.1038/35052055

46. Wang X, Hinson ER, Cresswell P. The Interferon-Inducible Protein Viperin Inhibits Influenza Virus Release by Perturbing Lipid Rafts. Cell Host Microbe (2007) 2(2):96-105. doi: 10.1016/j.chom.2007.06.009

47. Gizzi AS, Grove TL, Arnold JJ, Jose J, Jangra RK, Garforth SJ, et al. A Naturally Occurring Antiviral Ribonucleotide Encoded by the Human Genome. Nature (2018) 558(7711):610-4. doi: 10.1038/s41586-018-0238-4

48. Nguyen GT, Green ER, Mecsas J. Neutrophils to the ROScue: Mechanisms of NADPH Oxidase Activation and Bacterial Resistance. Front Cell Infect Microbiol (2017) 7:373. doi: 10.3389/fcimb.2017.00373

49. Shao DM, Segal AW, Dekker LV. Lipid Rafts Determine Efficiency of NADPH Oxidase Activation in Neutrophils. FEBS Lett (2003) 550(13):101-6. doi: 10.1016/S0014-5793(03)00845-7

50. Guichard C, Pedruzzi E, Dewas C, Fay M, Pouzet C, Bens M, et al. Interleukin-8-Induced Priming of Neutrophil Oxidative Burst Requires Sequential Recruitment of NADPH Oxidase Components Into Lipid Rafts. J Biol Chem (2005) 280(44):37021-32. doi: 10.1074/jbc.M506594200

51. Jin S, Zhou F, Katirai F, Li PL. Lipid Raft Redox Signaling: Molecular Mechanisms in Health and Disease. Antioxid Redox Signal (2011) 15 (4):1043-83. doi: 10.1089/ars.2010.3619

52. Shin DM, Yang CS, Lee JY, Lee SJ, Choi HH, Lee HM, et al. Mycobacterium Tuberculosis Lipoprotein-Induced Association of TLR2 With Protein Kinase C Zeta in Lipid Rafts Contributes to Reactive Oxygen Species-Dependent Inflammatory Signalling in Macrophages. Cell Microbiol (2008) 10(9):1893905. doi: 10.1111/j.1462-5822.2008.01179.x

53. Chen X, Li W, Ren J, Huang D, He WT, Song Y, et al. Translocation of Mixed Lineage Kinase Domain-Like Protein to Plasma Membrane Leads to Necrotic Cell Death. Cell Res (2014) 24(1):105-21. doi: 10.1038/cr.2013.171

54. Garofalo T, Matarrese P, Manganelli V, Marconi M, Tinari A, Gambardella $\mathrm{L}$, et al. Evidence for the Involvement of Lipid Rafts Localized at the ERMitochondria Associated Membranes in Autophagosome Formation. Autophagy (2016) 12(6):917-35. doi: 10.1080/15548627.2016.1160971

55. Manganelli V, Longo A, Mattei V, Recalchi S, Riitano G, Caissutti D, et al. Role of ERLINs in the Control of Cell Fate Through Lipid Rafts. Cells (2021) 10(9):2408. doi: 10.3390/cells10092408

56. Ciarlo L, Vona R, Manganelli V, Gambardella L, Raggi C, Marconi M, et al. Recruitment of Mitofusin 2 Into "Lipid Rafts" Drives Mitochondria Fusion Induced by Mdivi-1. Oncotarget (2018) 9(27):18869-84. doi: 10.18632/ oncotarget. 24792

57. Mercer J, Schelhaas M, Helenius A. Virus Entry by Endocytosis. Annu Rev Biochem (2010) 79:803-33. doi: 10.1146/annurev-biochem-060208-104626

58. Bukrinsky MI, Mukhamedova N, Sviridov D. Lipid Rafts and Pathogens: The Art of Deception and Exploitation. J Lipid Res (2019) 61:601-10. doi: 10.1194/jlr.TR119000391

59. Lorent JH, Diaz-Rohrer B, Lin X, Spring K, Gorfe AA, Levental KR, et al. Structural Determinants and Functional Consequences of Protein Affinity for Membrane Rafts. Nat Commun (2017) 8(1):1219. doi: 10.1038/s41467017-01328-3

60. Popik W, Alce TM, Au WC. Human Immunodeficiency Virus Type 1 Uses Lipid Raft-Colocalized CD4 and Chemokine Receptors for Productive Entry Into CD4(+) T Cells. J Virol (2002) 76(10):4709-22. doi: 10.1128/ jvi.76.10.4709-4722.2002

61. Nguyen DH, Taub D. CXCR4 Function Requires Membrane Cholesterol: Implications for HIV Infection. J Immunol (2002) 168(8):4121-6. doi: 10.4049/jimmunol.168.8.4121

62. Viard M, Parolini I, Sargiacomo M, Fecchi K, Ramoni C, Ablan S, et al. Role of Cholesterol in Human Immunodeficiency Virus Type 1 Envelope ProteinMediated Fusion With Host Cells. J Virol (2002) 76(22):11584-95. doi: 10.1128/jvi.76.22.11584-11595.2002

63. Gomes B, Sanna G, Madeddu S, Hollmann A, Santos NC. Combining 25Hydroxycholesterol With an HIV Fusion Inhibitor Peptide: Interaction With Biomembrane Model Systems and Human Blood Cells. ACS Infect Dis (2019) 5(4):582-91. doi: 10.1021/acsinfecdis.8b00321

64. Elahi S, Weiss RH, Merani S. Atorvastatin Restricts HIV Replication in CD4+ T Cells by Upregulation of P21. AIDS (2016) 30(2):171-83. doi: 10.1097/QAD.0000000000000917 
65. Selvam MP, Blay RA, Geyer S, Buck SM, Pollock L, Mayner RE, et al. Inhibition of HIV-1 Replication in H9 Cells by Nystatin-A Compared With Other Antiviral Agents. AIDS Res Hum Retroviruses (1993) 9(5):475-81. doi: 10.1089/aid.1993.9.475

66. Schroeder N, Chung CS, Chen CH, Liao CL, Chang W. The Lipid RaftAssociated Protein CD98 Is Required for Vaccinia Virus Endocytosis. J Virol (2012) 86(9):4868-82. doi: 10.1128/JVI.06610-11

67. Izmailyan R, Hsao JC, Chung CS, Chen CH, Hsu PW, Liao CL, et al. Integrin Betal Mediates Vaccinia Virus Entry Through Activation of PI3K/Akt Signaling. J Virol (2012) 86(12):6677-87. doi: 10.1128/JVI.06860-11

68. Chung CS, Huang CY, Chang W. Vaccinia Virus Penetration Requires Cholesterol and Results in Specific Viral Envelope Proteins Associated With Lipid Rafts. J Virol (2005) 79(3):1623-34. doi: 10.1128/JVI.79.3.16231634.2005

69. Takeda M, Leser GP, Russell CJ, Lamb RA. Influenza Virus Hemagglutinin Concentrates in Lipid Raft Microdomains for Efficient Viral Fusion. Proc Natl Acad Sci USA (2003) 100(25):14610-7. doi: 10.1073/pnas.2235620100

70. Verma DK, Gupta D, Lal SK. Host Lipid Rafts Play a Major Role in Binding and Endocytosis of Influenza A Virus. Viruses (2018) 10(11):650. doi: $10.3390 / \mathrm{v} 10110650$

71. Anderson HA, Chen Y, Norkin LC. Bound Simian Virus 40 Translocates to Caveolin-Enriched Membrane Domains, and Its Entry Is Inhibited by Drugs That Selectively Disrupt Caveolae. Mol Biol Cell (1996) 7(11):1825-34. doi: 10.1091/mbc.7.11.1825

72. Peng J, Zhang D, Ma Y, Wang G, Guo Z, Lu J. Protective Effect of Fluvastatin on Influenza Virus Infection. Mol Med Rep (2014) 9(6):2221-6. doi: 10.3892/ mmr.2014.2076

73. Luo Y, Motamedi N, Magaldi TG, Gee GV, Atwood WJ, DiMaio D. Interaction Between Simian Virus 40 Major Capsid Protein VP1 and Cell Surface Ganglioside GM1 Triggers Vacuole Formation. mBio (2016) 7(2): e00297. doi: 10.1128/mBio.00297-16

74. Huang H, Li Y, Sadaoka T, Tang H, Yamamoto T, Yamanishi K, et al. Human Herpesvirus 6 Envelope Cholesterol Is Required for Virus Entry. J Gen Virol (2006) 87(Pt 2):277-85. doi: 10.1099/vir.0.81551-0

75. Tang H, Kawabata A, Takemoto M, Yamanishi K, Mori Y. Human Herpesvirus-6 Infection Induces the Reorganization of Membrane Microdomains in Target Cells, Which Are Required for Virus Entry. Virology (2008) 378(2):265-71. doi: 10.1016/j.virol.2008.05.028

76. Kawabata A, Tang H, Huang H, Yamanishi K, Mori Y. Human Herpesvirus 6 Envelope Components Enriched in Lipid Rafts: Evidence for VirionAssociated Lipid Rafts. Virol J (2009) 6:127. doi: 10.1186/1743-422X-6-127

77. Santoro F, Kennedy PE, Locatelli G, Malnati MS, Berger EA, Lusso P. CD46 Is a Cellular Receptor for Human Herpesvirus 6. Cell (1999) 99(7):817-27. doi: 10.1016/s0092-8674(00)81678-5

78. Danthi P, Chow M. Cholesterol Removal by Methyl-Beta-Cyclodextrin Inhibits Poliovirus Entry. J Virol (2004) 78(1):33-41. doi: 10.1128/ jvi.78.1.33-41.2004

79. Martin-Acebes MA, Gonzalez-Magaldi M, Sandvig K, Sobrino F, ArmasPortela R. Productive Entry of Type C Foot-and-Mouth Disease Virus Into Susceptible Cultured Cells Requires Clathrin and Is Dependent on the Presence of Plasma Membrane Cholesterol. Virology (2007) 369(1):10518. doi: 10.1016/j.virol.2007.07.021

80. Kotecha A, Wang Q, Dong X, Ilca SL, Ondiviela M, Zihe R, et al. Rules of Engagement Between Alphavbeta6 Integrin and Foot-and-Mouth Disease Virus. Nat Commun (2017) 8:15408. doi: 10.1038/ncomms15408

81. Lee CJ, Lin HR, Liao CL, Lin YL. Cholesterol Effectively Blocks Entry of Flavivirus. J Virol (2008) 82(13):6470-80. doi: 10.1128/JVI.00117-08

82. Mukherjee S, Sengupta N, Chaudhuri A, Akbar I, Singh N, Chakraborty S, et al. PLVAP and GKN3 Are Two Critical Host Cell Receptors Which Facilitate Japanese Encephalitis Virus Entry Into Neurons. Sci Rep (2018) 8 (1):11784. doi: 10.1038/s41598-018-30054-z

83. Jones ST, Cagno V, Janecek M, Ortiz D, Gasilova N, Piret J, et al. Modified Cyclodextrins as Broad-Spectrum Antivirals. Sci Adv (2020) 6(5):eaax9318. doi: $10.1126 /$ sciadv.aax 9318

84. Shen TJ, Chen CL, Jhan MK, Tseng PC, Satria RD, Hsing CH, et al. Antiviral Efficacy of the Anesthetic Propofol Against Dengue Virus Infection and Cellular Inflammation. J Immunol Res 2021 (2021) p:6680913. doi: 10.1155/ $2021 / 6680913$
85. Lo YL, Liou GG, Lyu JH, Hsiao M, Hsu TL, Wong CH. Dengue Virus Infection Is Through a Cooperative Interaction Between a Mannose Receptor and CLEC5A on Macrophage as a Multivalent Hetero-Complex. PloS One (2016) 11(11):e0166474. doi: 10.1371/journal.pone.0166474

86. Tassaneetrithep B, Burgess TH, Granelli-Piperno A, Trumpfheller C, Finke J, Sun W, et al. DC-SIGN (CD209) Mediates Dengue Virus Infection of Human Dendritic Cells. J Exp Med (2003) 197(7):823-9. doi: 10.1084/jem.20021840

87. Medigeshi GR, Hirsch AJ, Streblow DN, Nikolich-Zugich J, Nelson JA. West Nile Virus Entry Requires Cholesterol-Rich Membrane Microdomains and Is Independent of Alphavbeta3 Integrin. J Virol (2008) 82(11):5212-9. doi: 10.1128/JVI.00008-08

88. Wang T, Town T, Alexopoulou L, Anderson JF, Fikrig E, Flavell RA. TollLike Receptor 3 Mediates West Nile Virus Entry Into the Brain Causing Lethal Encephalitis. Nat Med (2004) 10(12):1366-73. doi: 10.1038/nm1140

89. Choi KS, Aizaki H, Lai MM. Murine Coronavirus Requires Lipid Rafts for Virus Entry and Cell-Cell Fusion But Not for Virus Release. J Virol (2005) 79 (15):9862-71. doi: 10.1128/JVI.79.15.9862-9871.2005

90. Williams RK, Jiang GS, Holmes KV. Receptor for Mouse Hepatitis Virus Is a Member of the Carcinoembryonic Antigen Family of Glycoproteins. Proc Natl Acad Sci USA (1991) 88(13):5533-6. doi: 10.1073/pnas.88.13.5533

91. Guo H, Huang M, Yuan Q, Wei Y, Gao Y, Mao L, et al. The Important Role of Lipid Raft-Mediated Attachment in the Infection of Cultured Cells by Coronavirus Infectious Bronchitis Virus Beaudette Strain. PloS One (2017) 12(1):e0170123. doi: 10.1371/journal.pone.0170123

92. Winter C, Schwegmann-Wessels C, Cavanagh D, Neumann U, Herrler G. Sialic Acid Is a Receptor Determinant for Infection of Cells by Avian Infectious Bronchitis Virus. J Gen Virol (2006) 87(Pt 5):1209-16. doi: 10.1099/vir.0.81651-0

93. Nomura R, Kiyota A, Suzaki E, Kataoka K, Ohe Y, Miyamoto K, et al. Human Coronavirus 229E Binds to CD13 in Rafts and Enters the Cell Through Caveolae. J Virol (2004) 78(16):8701-8. doi: 10.1128/ JVI.78.16.8701-8708.2004

94. Yeager CL, Ashmun RA, Williams RK, Cardellichio CB, Shapiro LH, Look AT, et al. Human Aminopeptidase N Is a Receptor for Human Coronavirus 229E. Nature (1992) 357(6377):420-2. doi: 10.1038/357420a0

95. Kono M, Tatsumi K, Imai AM, Saito K, Kuriyama T, Shirasawa H. Inhibition of Human Coronavirus 229E Infection in Human Epithelial Lung Cells (L132) by Chloroquine: Involvement of P38 MAPK and ERK. Antiviral Res (2008) 77(2):150-2. doi: 10.1016/j.antiviral.2007.10.011

96. Lu Y, Liu DX, Tam JP. Lipid Rafts Are Involved in SARS-CoV Entry Into Vero E6 Cells. Biochem Biophys Res Commun (2008) 369(2):344-9. doi: $10.1016 / j . b b r c .2008 .02 .023$

97. Li W, Moore MJ, Vasilieva N, Sui J, Wong SK, Berne MA, et al. AngiotensinConverting Enzyme 2 Is a Functional Receptor for the SARS Coronavirus. Nature (2003) 426(6965):450-4. doi: 10.1038/nature02145

98. Wang S, Li W, Hui H, Tiwari SK, Zhang Q, Croker BA, et al. Cholesterol 25Hydroxylase Inhibits SARS-CoV-2 and Other Coronaviruses by Depleting Membrane Cholesterol. EMBO J (2020) 39(21):e106057. doi: 10.15252/ embj.2020106057

99. Li X, Zhu W, Fan M, Zhang J, Peng Y, Huang F, et al. Dependence of SARSCoV-2 Infection on Cholesterol-Rich Lipid Raft and Endosomal Acidification. Comput Struct Biotechnol J (2021) 19:1933-43. doi: 10.1016/ j.csbj.2021.04.001

100. Zu S, Deng YQ, Zhou C, Li J, Li L, Chen Q, et al. 25-Hydroxycholesterol Is a Potent SARS-CoV-2 Inhibitor. Cell Res (2020) 30(11):1043-5. doi: 10.1038/ s41422-020-00398-1

101. Zapatero-Belinchon FJ, Moeller R, Lasswitz L, van Ham M, Becker M, Brogden G, et al. Fluvastatin Mitigates SARS-CoV-2 Infection in Human Lung Cells. iScience (2021) 24(12):103469. doi: 10.1016/j.isci.2021.103469

102. Lenze EJ, Mattar C, Zorumski CF, Stevens A, Schweiger J, Nicol GE, et al. Fluvoxamine vs Placebo and Clinical Deterioration in Outpatients With Symptomatic COVID-19: A Randomized Clinical Trial. JAMA (2020) 324 (22):2292-300. doi: 10.1001/jama.2020.22760

103. Sanchez-Torres C, Gomez-Puertas P, Gomez-del-Moral M, Alonso F, Escribano JM, Ezquerra A, et al. Expression of Porcine CD163 on Monocytes/Macrophages Correlates With Permissiveness to African Swine Fever Infection. Arch Virol (2003) 148(12):2307-23. doi: 10.1007/s00705003-0188-4 
104. Galindo I, Cuesta-Geijo MA, Hlavova K, Munoz-Moreno R, Barrado-Gil L, Dominguez J, et al. African Swine Fever Virus Infects Macrophages, the Natural Host Cells, via Clathrin- and Cholesterol-Dependent Endocytosis. Virus Res (2015) 200:45-55. doi: 10.1016/j.virusres.2015.01.022

105. Li C, Deng YQ, Wang S, Ma F, Aliyari R, Huang XY, et al. 25Hydroxycholesterol Protects Host Against Zika Virus Infection and Its Associated Microcephaly in a Mouse Model. Immunity (2017) 46(3):44656. doi: 10.1016/j.immuni.2017.02.012

106. Hamel R, Dejarnac O, Wichit S, Ekchariyawat P, Neyret A, Luplertlop N, et al. Biology of Zika Virus Infection in Human Skin Cells. J Virol (2015) 89 (17):8880-96. doi: 10.1128/JVI.00354-15

107. Bader T, Fazili J, Madhoun M, Aston C, Hughes D, Rizvi S, et al. Fluvastatin Inhibits Hepatitis C Replication in Humans. Am J Gastroenterol (2008) 103 (6):1383-9. doi: 10.1111/j.1572-0241.2008.01876.x

108. Cocquerel L, Voisset C, Dubuisson J. Hepatitis C Virus Entry: Potential Receptors and Their Biological Functions. J Gen Virol (2006) 87(Pt 5):107584. doi: 10.1099/vir.0.81646-0

109. Gower TL, Graham BS. Antiviral Activity of Lovastatin Against Respiratory Syncytial Virus In Vivo and In Vitro. Antimicrob Agents Chemother (2001) 45(4):1231-7. doi: 10.1128/AAC.45.4.1231-1237.2001

110. Ravi LI, Li L, Wong PS, Sutejo R, Tan BH, Sugrue RJ. Lovastatin Treatment Mitigates the Pro-Inflammatory Cytokine Response in Respiratory Syncytial Virus Infected Macrophage Cells. Antiviral Res (2013) 98(2):332-43. doi: 10.1016/j.antiviral.2013.03.015

111. Griffiths CD, Bilawchuk LM, McDonough JE, Jamieson KC, Elawar F, Cen Y, et al. IGF1R Is an Entry Receptor for Respiratory Syncytial Virus. Nature (2020) 583(7817):615-9. doi: 10.1038/s41586-020-2369-7

112. Anderson CS, Chirkova T, Slaunwhite CG, Qiu X, Walsh EE, Anderson LJ, et al. CX3CR1 Engagement by Respiratory Syncytial Virus Leads to Induction of Nucleolin and Dysregulation of Cilia-Related Genes. J Virol (2021) 95:e00095-21. doi: 10.1128/JVI.00095-21

113. Shrivastava-Ranjan P, Flint M, Bergeron E, McElroy AK, Chatterjee P, Albarino CG, et al. Statins Suppress Ebola Virus Infectivity by Interfering With Glycoprotein Processing. mBio (2018) 9(3):e00660-18. doi: 10.1128/ mBio.00660-18

114. Brunton B, Rogers K, Phillips EK, Brouillette RB, Bouls R, Butler NS, et al. TIM-1 Serves as a Receptor for Ebola Virus In Vivo, Enhancing Viremia and Pathogenesis. PloS Negl Trop Dis (2019) 13(6):e0006983. doi: 10.1371/ journal.pntd.0006983

115. WuDunn D, Spear PG. Initial Interaction of Herpes Simplex Virus With Cells Is Binding to Heparan Sulfate. J Virol (1989) 63(1):52-8. doi: 10.1128/ JVI.63.1.52-58.1989

116. Benkahla MA, Alidjinou EK, Sane F, Desailloud R, Hober D. Fluoxetine can Inhibit Coxsackievirus-B4 E2 In Vitro and In Vivo. Antiviral Res (2018) 159:130-3. doi: 10.1016/j.antiviral.2018.10.002

117. Manganaro R, Zonsics B, Bauer L, Lorenzo Lopez M, Donselaar T, Zwaagstra M, et al. Synthesis and Antiviral Effect of Novel Fluoxetine Analogues as Enterovirus 2C Inhibitors. Antiviral Res (2020) 178:104781. doi: 10.1016/ j.antiviral.2020.104781

118. Messacar K, Sillau S, Hopkins SE, Otten C, Wilson-Murphy M, Wong B, et al. Safety, Tolerability, and Efficacy of Fluoxetine as an Antiviral for Acute Flaccid Myelitis. Neurology (2019) 92(18):e2118-26. doi: 10.1212/ WNL.0000000000006670

119. Yamayoshi S, Fujii K, Koike S. Receptors for Enterovirus 71. Emerg Microbes Infect (2014) 3(7):e53. doi: 10.1038/emi.2014.49

120. Bedows E, Davidson BA, Knight PR. Effect of Halothane on the Replication of Animal Viruses. Antimicrob Agents Chemother (1984) 25(6):719-24. doi: 10.1128/AAC.25.6.719

121. Dhiman N, Jacobson RM, Poland GA. Measles Virus Receptors: SLAM and CD46. Rev Med Virol (2004) 14(4):217-29. doi: 10.1002/rmv.430

122. Blanc M, Hsieh WY, Robertson KA, Watterson S, Shui G, Lacaze P, et al. Host Defense Against Viral Infection Involves Interferon Mediated DownRegulation of Sterol Biosynthesis. PloS Biol (2011) 9(3):e1000598. doi: 10.1371/journal.pbio.1000598

123. Pontejo SM, Murphy PM. Mouse Cytomegalovirus Differentially Exploits Cell Surface Glycosaminoglycans in a Cell Type-Dependent and MCK-2Independent Manner. Viruses (2019) 12(1):31. doi: 10.3390/v12010031
124. Chung CS, Hsiao JC, Chang YS, Chang W. A27L Protein Mediates Vaccinia Virus Interaction With Cell Surface Heparan Sulfate. J Virol (1998) 72 (2):1577-85. doi: 10.1128/JVI.72.2.1577-1585.1998

125. Lafont F, Tran Van Nhieu G, Hanada K, Sansonetti P, van der Goot FG. Initial Steps of Shigella Infection Depend on the Cholesterol/Sphingolipid Raft-Mediated CD44-IpaB Interaction. EMBO J (2002) 21(17):4449-57. doi: 10.1093/emboj/cdf457

126. Knodler LA, Vallance BA, Hensel M, Jackel D, Finlay BB, Steele-Mortimer O. Salmonella Type III Effectors PipB and PipB2 Are Targeted to DetergentResistant Microdomains on Internal Host Cell Membranes. Mol Microbiol (2003) 49(3):685-704. doi: 10.1046/j.1365-2958.2003.03598.x

127. Hartlova A, Cerveny L, Hubalek M, Krocova Z, Stulik J. Membrane Rafts: A Potential Gateway for Bacterial Entry Into Host Cells. Microbiol Immunol (2010) 54(4):237-45. doi: 10.1111/j.1348-0421.2010.00198.x

128. Hoffmann C, Berking A, Agerer F, Buntru A, Neske F, Chhatwal GS, et al. Caveolin Limits Membrane Microdomain Mobility and Integrin-Mediated Uptake of Fibronectin-Binding Pathogens. J Cell Sci (2010) 123(Pt 24):428091. doi: $10.1242 /$ jcs. 064006

129. Yuan K, Huang C, Fox J, Gaid M, Weaver A, Li G, et al. Elevated Inflammatory Response in Caveolin-1-Deficient Mice With Pseudomonas Aeruginosa Infection Is Mediated by STAT3 Protein and Nuclear Factor kappaB (NF-Kappab). J Biol Chem (2011) 286(24):21814-25. doi: 10.1074/ jbc.M111.237628

130. Brandstaetter H, Kendrick-Jones J, Buss F. Myolc Regulates Lipid Raft Recycling to Control Cell Spreading, Migration and Salmonella Invasion. J Cell Sci (2012) 125(Pt 8):1991-2003. doi: 10.1242/jcs.097212

131. Codrici E, Albulescu L, Popescu ID, Mihai S, Enciu AM, Albulescu R, et al. Caveolin-1-Knockout Mouse as a Model of Inflammatory Diseases. J Immunol Res (2018) 2018:2498576. doi: 10.1155/2018/2498576

132. Rai A, Pathak D, Thakur S, Singh S, Dubey AK, Mallik R. Dynein Clusters Into Lipid Microdomains on Phagosomes to Drive Rapid Transport Toward Lysosomes. Cell (2016) 164(4):722-34. doi: 10.1016/j.cell.2015.12.054

133. Morita E, Sandrin V, McCullough J, Katsuyama A, Baci Hamilton I, Sundquist WI. ESCRT-III Protein Requirements for HIV-1 Budding. Cell Host Microbe (2011) 9(3):235-42. doi: 10.1016/j.chom.2011.02.004

134. Huttunen M, Samolej J, Evans RJ, Yakimovich A, White IJ, Kriston-Vizi J, et al. Vaccinia Virus Hijacks ESCRT-Mediated Multivesicular Body Formation for Virus Egress. Life Sci Alliance (2021) 4(8):e202000910. doi: 10.26508/sa.202000910

135. Meng B, Ip NC, Prestwood LJ, Abbink TE, Lever AM. Evidence That the Endosomal Sorting Complex Required for Transport-II (ESCRT-II) Is Required for Efficient Human Immunodeficiency Virus-1 (HIV-1) Production. Retrovirology (2015) 12:72. doi: 10.1186/s12977-015-0197-x

136. Bartusch C, Prange R. ESCRT Requirements for Murine Leukemia Virus Release. Viruses (2016) 8(4):103. doi: 10.3390/v8040103

137. Christ L, Raiborg C, Wenzel EM, Campsteijn C, Stenmark H. Cellular Functions and Molecular Mechanisms of the ESCRT Membrane-Scission Machinery. Trends Biochem Sci (2017) 42(1):42-56. doi: 10.1016/ j.tibs.2016.08.016

138. Dubois L, Ronquist KK, Ek B, Ronquist G, Larsson A. Proteomic Profiling of Detergent Resistant Membranes (Lipid Rafts) of Prostasomes. Mol Cell Proteomics (2015) 14(11):3015-22. doi: 10.1074/mcp.M114.047530

139. Martinez-Gutierrez M, Castellanos JE, Gallego-Gomez JC. Statins Reduce Dengue Virus Production via Decreased Virion Assembly. Intervirology (2011) 54(4):202-16. doi: 10.1159/000321892

140. Sviridov D, Miller YI, Ballout RA, Remaley AT, Bukrinsky M. Targeting Lipid Rafts-A Potential Therapy for COVID-19. Front Immunol (2020) 11:574508. doi: 10.3389/fimmu.2020.574508

141. Tsuchiya H, Mizogami M. Interaction of drugs with lipid raft membrane domains as a possible target. Drug Target Insights (2020) 14:34-47. doi: $10.33393 / \mathrm{dti} .2020 .2185$

142. Mahammad S, Parmryd I. Cholesterol Depletion Using Methyl-BetaCyclodextrin. Methods Mol Biol (2015) 1232:91-102. doi: 10.1007/978-14939-1752-5_8

143. Braga SS, Barbosa JS, Santos NE, El-Saleh F, Paz FAA. Cyclodextrins in Antiviral Therapeutics and Vaccines. Pharmaceutics (2021) 13(3):409. doi: 10.3390/pharmaceutics13030409 
144. Parihar SP, Guler R, Brombacher F. Statins: A Viable Candidate for HostDirected Therapy Against Infectious Diseases. Nat Rev Immunol (2019) 19 (2):104-17. doi: 10.1038/s41577-018-0094-3

145. Gorabi AM, Kiaie N, Bianconi V, Jamialahmadi T, Al-Rasadi K, Johnston TP, et al. Antiviral Effects of Statins. Prog Lipid Res (2020) 79:101054. doi: $10.1016 /$ j.plipres.2020.101054

146. Pavel MA, Petersen EN, Wang H, Lerner RA, Hansen SB. Studies on the Mechanism of General Anesthesia. Proc Natl Acad Sci USA (2020) 117 (24):13757-66. doi: 10.1073/pnas.2004259117

147. Golden SR, Rosenstein DL, Belhorn T, Blatt J. Repurposing Psychotropic Agents for Viral Disorders: Beyond Covid. Assay Drug Dev Technol (2021) 19 (6):373-85. doi: 10.1089/adt.2021.014

148. Otreba M, Kosmider L, Rzepecka-Stojko A. Antiviral Activity of Chlorpromazine, Fluphenazine, Perphenazine, Prochlorperazine, and Thioridazine Towards RNA-Viruses. A Review. Eur J Pharmacol (2020) 887:173553. doi: 10.1016/j.ejphar.2020.173553

149. Erb SJ, Schappi JM, Rasenick MM. Accumulate in Lipid Rafts Independent of Monoamine Transporters to Modulate Redistribution of the G Protein, Galphas. J Biol Chem (2016) 291(38):19725-33. doi: 10.1074/jbc. M116.727263

150. Singh H, Wray N, Schappi JM, Rasenick MM. Disruption of Lipid-Raft Localized Galphas/tubulin Complexes by Antidepressants: A Unique Feature of HDAC6 Inhibitors, SSRI and Tricyclic Compounds. Neuropsychopharmacology (2018) 43 (7):1481-91. doi: 10.1038/s41386-018-0016-x

151. van Zon A, Mossink MH, Scheper RJ, Sonneveld P, Wiemer EA. The Vault Complex. Cell Mol Life Sci (2003) 60(9):1828-37. doi: 10.1007/s00018-0033030-y

152. Steiner E, Holzmann K, Elbling L, Micksche M, Berger W. Cellular Functions of Vaults and Their Involvement in Multidrug Resistance. Curr Drug Targets (2006) 7(8):923-34. doi: 10.2174/138945006778019345

153. Scheffer GL, Schroeijers AB, Izquierdo MA, Wiemer EA, Scheper RJ. Lung Resistance-Related Protein/Major Vault Protein and Vaults in MultidrugResistant Cancer. Curr Opin Oncol (2000) 12(6):550-6. doi: 10.1097/ 00001622-200011000-00007

154. Mossink MH, van Zon A, Scheper RJ, Sonneveld P, Wiemer EA. Vaults: A Ribonucleoprotein Particle Involved in Drug Resistance? Oncogene (2003) 22 (47):7458-67. doi: 10.1038/sj.onc.1206947

155. Wojtowicz K, Januchowski R, Nowicki M, Zabel M. vPARP Adjusts MVP Expression in Drug-Resistant Cell Lines in Conjunction With MDR Proteins. Anticancer Res (2017) 37(6):3015-23. doi: 10.21873/ anticanres. 11656

156. Steiner E, Holzmann K, Pirker C, Elbling L, Micksche M, Sutterluty H, et al. The Major Vault Protein Is Responsive to and Interferes With InterferonGamma-Mediated STAT1 Signals. J Cell Sci (2006) 119(Pt 3):459-69. doi: $10.1242 /$ jcs. 02773

157. Kolli S, Zito CI, Mossink MH, Wiemer EA, Bennett AM. The Major Vault Protein Is a Novel Substrate for the Tyrosine Phosphatase SHP-2 and Scaffold Protein in Epidermal Growth Factor Signaling. J Biol Chem (2004) 279(28):29374-85. doi: 10.1074/jbc.M313955200

158. Ben J, Jiang B, Wang D, Liu Q, Zhang Y, Qi Y, et al. Major Vault Protein Suppresses Obesity and Atherosclerosis Through Inhibiting IKK-NF-kappaB Signaling Mediated Inflammation. Nat Commun (2019) 10(1):1801. doi: 10.1038/s41467-019-09588-x
159. Yuan L, Zhao N, Wang J, Liu Y, Meng L, Guo S, et al. Major Vault Protein (MVP) Negatively Regulates Osteoclastogenesis via Calcineurin-NFATc1 Pathway Inhibition. Theranostics (2021) 11(15):7247-61. doi: 10.7150/ thno. 58468

160. Kim E, Lee S, Mian MF, Yun SU, Song M, Yi KS, et al. Crosstalk Between Src and Major Vault Protein in Epidermal Growth Factor-Dependent Cell Signalling. FEBS J (2006) 273(4):793-804. doi: 10.1111/j.17424658.2006.05112.x

161. Motsch N, Pfuhl T, Mrazek J, Barth S, Grasser FA. Epstein-Barr VirusEncoded Latent Membrane Protein 1 (LMP1) Induces the Expression of the Cellular microRNA miR-146a. RNA Biol (2007) 4(3):131-7. doi: 10.4161/ rna.4.3.5206

162. Mrazek J, Kreutmayer SB, Grasser FA, Polacek N, Huttenhofer A. Subtractive Hybridization Identifies Novel Differentially Expressed ncRNA Species in EBV-Infected Human B Cells. Nucleic Acids Res (2007) 35(10): e73. doi: 10.1093/nar/gkm244

163. Kowalski MP, Dubouix-Bourandy A, Bajmoczi M, Golan DE, Zaidi T, Coutinho-Sledge YS, et al. Host Resistance to Lung Infection Mediated by Major Vault Protein in Epithelial Cells. Science (2007) 317(5834):130-2. doi: 10.1126/science.1142311

164. Rayo J, Gregor R, Jacob NT, Dandela R, Dubinsky L, Yashkin A, et al. Immunoediting Role for Major Vault Protein in Apoptotic Signaling Induced by Bacterial N-Acyl Homoserine Lactones. Proc Natl Acad Sci USA (2021) 118(12):e2012529118. doi: 10.1073/pnas.2012529118

165. Ben J, Zhang Y, Zhou R, Zhang H, Zhu X, Li X, et al. Major Vault Protein Regulates Class A Scavenger Receptor-Mediated Tumor Necrosis FactorAlpha Synthesis and Apoptosis in Macrophages. J Biol Chem (2013) 288 (27):20076-84. doi: 10.1074/jbc.M112.449538

166. Mossink MH, van Zon A, Franzel-Luiten E, Schoester M, Kickhoefer VA, Scheffer GL, et al. Disruption of the Murine Major Vault Protein (MVP/LRP) Gene Does Not Induce Hypersensitivity to Cytostatics. Cancer Res (2002) 62 (24):7298-304. doi: 10.1038/sj.onc.1206947

167. Peng N, Liu S, Xia Z, Ren S, Feng J, Jing M, et al. Inducible Major Vault Protein Plays a Pivotal Role in Double-Stranded RNA- or Virus-Induced Proinflammatory Response. J Immunol (2016) 196(6):2753-66. doi: 10.4049/ jimmunol.1501481

Conflict of Interest: The authors declare that the research was conducted in the absence of any commercial or financial relationships that could be construed as a potential conflict of interest.

Publisher's Note: All claims expressed in this article are solely those of the authors and do not necessarily represent those of their affiliated organizations, or those of the publisher, the editors and the reviewers. Any product that may be evaluated in this article, or claim that may be made by its manufacturer, is not guaranteed or endorsed by the publisher.

Copyright (c) 2022 Kulkarni, Wiemer and Chang. This is an open-access article distributed under the terms of the Creative Commons Attribution License (CC BY). The use, distribution or reproduction in other forums is permitted, provided the original author(s) and the copyright owner(s) are credited and that the original publication in this journal is cited, in accordance with accepted academic practice. No use, distribution or reproduction is permitted which does not comply with these terms. 